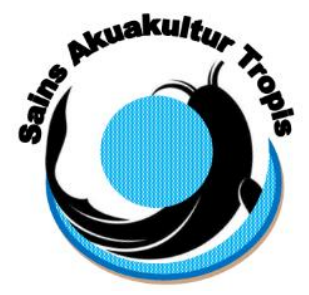

\author{
Jurnal Sains Akuakultur Tropis \\ Departemen Akuakultur \\ Fakultas Perikanan dan IImu Kelautan - Universitas Diponegoro \\ JI. Prof. Soedarto, SH, Tembalang, Semarang 50275 \\ Telp. (024) 7474698, Fax.: (024) 7474698 \\ Email: sainsakuakulturtropis@gmail.com, sainsakuakulturtropis@undip.ac.id
}

\title{
PENGARUH PENAMBAHAN BAKTERI KANDIDAT PROBIOTIK Bacillus methylothropicus pada PAKAN BUATAN TERHADAP PROFIL DARAH DAN \\ PERFORMA PERTUMBUHAN IKAN NILA (Oreochromis niloticus) yang DIUJI TANTANG dengan BAKTERI Aeromonas hydrophila
}

The Effect of Probiotic Candidate Bacteria Bacillus methylothropicus in Commercial Feed on Blood Profile and

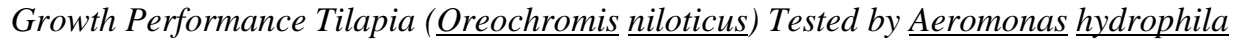

\author{
Adi Putra Kurniawan, Suminto*, A.H.Condro Haditomo \\ Departemen Akuakultur \\ Fakultas Perikanan dan Ilmu Kelutan, Universitas Diponegoro \\ J1. Prof. Soedarto, SH, Tembalang, Semarang, Jawa Tengah - 50275, Telp/Fax. +6224 7474698 \\ * Corresponding author: suminto57@gmail.com
}

\begin{abstract}
ABSTRAK
Ikan nila (O.niloticus) merupakan salah satu komoditas ikan air tawar dengan nilai ekonomis penting dan mempunyai nutrisi yang cukup tinggi. Peningkatan produksi budidaya dapat dilakukan dengan efisiensi pemanfaatan pakan sebagai upaya memenuhi kebutuhan konsumsi ikan nila. Upaya yang dapat dilakukan yaitu penggunaan enzim eksogenus dengan penambahan probiotik penghasil enzim ke dalam pakan yang mampu meningkatkan efisiensi pakan karena lebih mudah dicerna dan enzim dapat bekerja lebih efektif dalam meningkatkan kinerja pertumbuhan dan respons imun ikan nila. B.methylotrophicus merupakan salah satu kandidat bakteri probiotik yang diduga mampu meningkatkan pertumbuhan dan respons imun ikan. Penelitian ini bertujuan untuk mengkaji pengaruh penambahan bakteri kandidat probiotik B.methylotrophicus pada pakan buatan terhadap efisiensi pemanfaatan pakan, pertumbuhan, rasio konversi pakan, kelulushidupan, serta pengaruhnya terhadap gejala klinis, profil darah ikan nila (O.niloticus) yang diuji tantang terhadap A. hydrophila. Ikan uji yang digunakan adalah ikan nila (O.niloticus) dengan bobot rata-

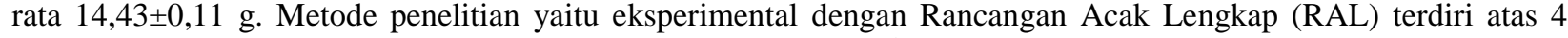
perlakuan dengan 3 ulangan yaitu perlakuan A (0 CFU/mL), B $\left(10^{5} \mathrm{CFU} / \mathrm{mL}\right), \mathrm{C}\left(10^{7} \mathrm{CFU} / \mathrm{mL}\right) \mathrm{dan} \mathrm{D}\left(10^{9} \mathrm{CFU} / \mathrm{mL}\right)$. Hasil penelitian menunjukkan bahwa berpengaruh nyata $(\mathrm{P}<0,05)$ terhadap laju pertumbuhan relatif $(\mathrm{RGR})$ dan kelulushidupan $(\mathrm{SR})$ namun tidak berpengaruh nyata $(\mathrm{P}>0,05)$ terhadap efisiensi pemanfaatan pakan $(\mathrm{EPP})$ dan rasio konversi pakan (FCR) ikan nila (O.niloticus). Hasil berpengaruh terhadap dinamika profil darah ikan nila (O.niloticus) yang diuji tantang dengan gejala klinis menunjukkan adanya infeksi. Hasil tersebut menunjukkan bahwa B.methylotrophicus mampu menghambat pertumbuhan A.hydrophila secara in vitro, dan belum mendapat hasil maksimal pada $10^{9} \mathrm{CFU} / \mathrm{mL}$.
\end{abstract}

Kata kunci: Nila, B. methylotrophicus, kandidat probiotik, pertumbuhan, profil darah

\begin{abstract}
Nile tilapia is one of economically important freshwater fish commodities and has high enough nutrition. The increasing production can be done with feed efficiency to meet a need comsumption of nile tilapia. The efforts that can be made is use an exogenous enzyme with the addition of probiotic that produce an enzymes added into the feed that is able to increase feed efficiency because more easily to digest and the enzymes more effective to improve growth performance and immune response of nile tilapia. B. methylotrophicus is one of probiotic candidate bacteria that may be able to increase the growth and immune response of fish. The aims of this research was to find out additional probiotic candidate bacteria on comercial feed toward the efficiency of feed utilization, growth, feed conversion ratio and survival rate, and the effects on clinical symptoms, blood profile of tilapia (O.niloticus) tested with A. hydrophila
\end{abstract}


The fish that used for experiment were nile tilapia $(14,43 \pm 0,11 \mathrm{~g})$. This study applied an experimental method with Completely Randomized Design (RAL). The treatments were A (O CFU/mL), B (10 CFU/mL), C (10 $\mathrm{CFU} / \mathrm{mL})$ dan $D\left(10^{9} \mathrm{CFU} / \mathrm{mL}\right)$. The results has significantly different $(P<0,05)$ on $R G R$ and Survival but has not significantly different $(P>0.05)$ on EPP and FCR of nile tilapia. The additional of B.methylotrophicus has an effect dynamics of blood profiles with clinical symtoms showed infection. The results showed that was able to inhibit the growth of A.hydrophila (in vitro), and had not yet obtained maximum result at $10^{9} \mathrm{CFU} / \mathrm{mL}$.

Keywords: tilapia, B.methylotrophicus, probiotic candidate, growth, blood profile

Article Received: 20-12-2018; Accepted: 12-01-2019

\section{PENDAHULUAN}

Ikan nila (O.niloticus) merupakan salah satu komoditas ikan air tawar yang banyak dibudidayakan dan banyak diminati oleh masyarakat. Ikan nila mudah berkembangbiak, tumbuh cepat, dapat hidup dan berkembangbiak di air payau, dan merupakan ikan omnivora dan cenderung herbivora (Nasution et al., 2014). Menurut Ramadhana et.al. (2012) merupakan salah satu spesies ikan yang banyak dibudidayakan untuk memenuhi kebutuhan protein hewani dan konsumsi.

Peminatan masyarakat akan ikan nila berpengaruh terhadap peningkatan produksi ikan dalam memenuhi kebutuhan tersebut, sehingga membutuhkan pakan lebih. Harga bahan baku pakan yang berkualitas semakin meningkat, maka perlu dilakukan upaya efisiensi pakan yang diberikan untuk memenuhi kebutuhan tersebut dalam rangka peningkatan produksi ikan, menurut Haetami et.al. (2008) pakan merupakan faktor penentu pertumbuhan dan merupakan biaya terbesar dalam produksi (60-70\%). Meningkatnya intensifikasi budidaya juga memiliki dampak terhadap serangan penyakit pada ikan nila khususnya A.hydrophila, sedangkan menurut Indriani et.al. (2014), saat ini bahan yang sering digunakan untuk menanggulangi penyakit pada ikan budidaya adalah pengobatan dengan zat kimia antibiotik yang menurut Haditomo et.al. (2016) antibiotik dapat menjadikan patogen-patogen menjadi resisten.

Beberapa cara dapat dilakukan sebagai upaya efisiensi penggunaan pakan dalam rangka adanya kebutuhan pakan yang lebih. Penambahan probiotik penghasil enzim ke dalam pakan dapat meningkatkan efisiensi pakan sehingga lebih mudah dicerna dan enzim dapat bekerja lebih efektif dalam meningkatkan kinerja pertumbuhan, hal tersebut diperkuat Mulyadi (2011) bahwa bakteri probotik dalam pakan menyebabkan aktivitas bakteri probiotik dapat bekerja secara maksimal dalam pencernaan ikan, sehingga daya cerna ikan pun menjadi lebih tinggi dalam menyerap sari-sari makanan dan menghasilan pertumbuhan yang baik. Permasalahan lain budidaya ikan nila yaitu berupa serangan penyakit, dapat ditanggulangi dengan penambahan probiotik pada pakan karena mampu meningkatkan imunitas kultivan. Aplikasi probiotik dapat pula berfungsi sebagai agen biokontrol untuk mengurangi serangan penyakit (Widanarni et al., 2008).

Studi mengenai bakteri kandidat probiotik untuk mengetahui kelayakan suatu bakteri dapat dikatakan sebagai bakteri probiotik. Seleksi bakteri sebagai kandidat probiotik dapat didasarkan pada kemampuannya yang mampu tumbuh dalam berbagai lingkungan (Hong et al., 2005), bakteri probiotik mampu menghambat pertumbuhan bakteri patogen, meningatkan respons imun, kelangsungan hidup ikan (Aji et al., 2014) dan meningkatkan kinerja pertumbuhan (Septiana et al., 2017). Bakteri kandidat probiotik lain yang berpotensi mampu meningkatkan daya cerna ikan dan menghambat pertumbuhan A.hydrophila adalah B.methylotrophicus yang ditemukan oleh Haditomo et.al. (2017), dengan kode isolat CBL20 yang diharapkan mampu meningkatkan daya cerna pakan dan salah satu solusi untuk pencegahan serangan patogen pada ikan nila.

Penelitian ini bertujuan mengkaji dinamika gejala klinis dan profil darah ikan nila (O. niloticus) yang diuji tantang bakteri A. hydrophila dan diberi pakan buatan dengan penambahan bakteri kandidat probiotik, dan mengkaji pengaruhnya terhadap performa pertumbuhan. Serta untuk mengetahui pengaruh penambahan bakteri kandidat probiotik dalam pakan buatan terhadap gejala klinis, profil darah ikan nila (O.niloticus) yang diuji tantang A. hydrophila. Penelitian ini dilaksanakan pada Mei 2018 - Juli 2018 di Laboratorium Departemen Akuakultur, Fakultas Perikanan dan Ilmu Kelautan, Universitas Diponegoro, Semarang.

\section{MATERI DAN METODE}

\section{Kultur Bakteri Bacillus methylothropicus dan Bakteri Patogenik}

Tahap persiapan terdiri dari sterilisasi alat dan bahan, aklimatisasi ikan uji pembuatan media bakteri, kultur bakteri dan pengganasan bakteri. Alat-alat mikrobiologi disterilkan dengan cara dicuci kemudian diautoclave. Bakteri kandidat probiotik yang digunakan adalah bakteri yang diperoleh Haditomo et al., (2017) dengan kode isolat CBL20 yang merupakan hasil screening atau penapisan bakteri lumpur budidaya ikan nila di Boyolali, Jawa Tengah. Bakteri ini telah diidentifikasi berdasarkan analisis sequence 16 sRNA dan kemudian membandingkan dengan sequence di NCBI sehingga diperoleh jenis bakteri B.methylotrophicus strain XJAJ2 dengan tingkat homologi 100\%. Bakteri patogen yang digunakan dalam penelitian ini adalah A. hydrophila. Isolat murni A. hydrophila diperoleh proses isolasi 
bakteri pada media budidaya ikan nila di Laboratorium Basah Departemen Akuakultur, Universitas Diponegoro yang telah dilakukan uji biokimia untuk proses identifikasi. Media penumbuhan bakteri yang digunakan adalah media TSA (Trypticase Soya Agar), media selektif GSP (Glutamate Starch Phenol), media TSB (Tryptic Soy Broth). Uji pengganasan bakteri dilakukan untuk meningkatkan virulensi bakteri A.hydrophila terhadap ikan nila yang digunakan sebagai uji tantang. Menurut Nastiti (2017) bakteri yang akan di gunakan sebagai bahan uji, dikultur kembali dan ditingkatkan patogenisitasnya (phasase). Tahapan uji pasase dimulai dari kultur bakteri A.hydrophila dalam media cair TSB dari isolat murni pada TSA miring. Setelah diinkubasi selama 24 jam, bakteri dapat digunakan untuk uji pengganasan. Ikan nila diinfeksi dengan isolat A. hydrophila. Proses penginfeksian bakteri dilakukan dengan penginjeksian secara Intramuscular. Uji Pasase dilakukan sebanyak 3 kali dan isolat murni yang telah didapatkan kemudian dikultur di media TSB untuk digunakan dalam proses pasase kembali hingga siap untuk uji tantang.

\section{Persiapan Pakan Berprobiotik}

Pakan dasar yang digunakan dalam penelitian adalah pakan komersil berbentuk pellet produksi dari PT. Central Proteina Prima (CPP) dengan kode FF-999 dengan kandungan protein 38-42\%. Pakan uji yang digunakan merupakan pakan dasar yang ditambah dengan bakteri kandiidat probiotik sesuai dengan perlakuan dengan cara spray (disemprot). Metode pemberian pakan mengacu pada Ardita et.al. (2015), bahwa pemberian pakan pada ikan nila yang dilakukan secara at satiation. Menurut Hanief et.al. (2014) Pemberian pakan dilakukan dengan metode at satiation, yakni pakan diberikan sedikit demi sedikit sampai 80\% ikan tidak lagi merespon pakan yang diberikan. Dosis pemberian bakteri kandidat probiotik yang diberikan pada masing-masing perlakuan sebanyak $1 \mathrm{mLuntuk}$ setiap $10 \mathrm{~g}$, memodifikasi dari hasil penelitian Fadri et.al. (2016) bahwa dosis optimum probiotik EM-4 pada pakan adalah sebanyak $5 \mathrm{~mL} / \mathrm{kg}$. Persiapan pakan uji mengacu pada Suminto dan Chilmawati (2015), dengan cara menyemprotkan ke permukaan pakan yang diberikan. Pakan yang sudah disemprot dengan bakteri probiotik tersebut diinkubasi pada suhu kamar selama 24 jam, dan siap digunakan sebagai pakan. Frekuensi pemberian pakan dilakukan 3 kali sehari.

\section{Metode dan Rancangan Percobaan}

Metode yang digunakan dalam penelitian adalah metode penelitian eksperimental. Metode eksperimental yaitu melihat hubungan sebab akibat dari satu atau lebih variabel terikat dengan satu atau lebih variabel kontrol. Penelitian dengan melakukan manipulasi terhadap satu atau lebih variabel terikat. Manipulasi berarti merubah secara sistematis sifat (nilai-nilai) variabel bebas sesuai dengan tujuan penelitian (Setyanto, 2005). Rancangan percobaan yang digunakan dalam penelitian ini adalah rancangan acak lengkap (RAL) dengan menggunakan 4 perlakuan dan 3 ulangan. Perlakuan yang dilakukan dalam penelitian ini adalah sebagai berikut: Perlakuan A yaitu pakan buatan tanpa tambahan bakteri kandidat probiotik $0 \mathrm{CFU} / \mathrm{mL}+\mathrm{Uji}$ tantang bakteri A.hydrophila. Perlakuan B yaitu pakan buatan dengan tambahan bakteri kandidat probiotik kepadatan $10^{5} \mathrm{CFU} / \mathrm{mL}+\mathrm{Uji}$ tantang bakteri A.hydrophila. Perlakuan C yaitu pakan buatan dengan tambahan bakteri kandidat probiotik kepadatan $10^{7} \mathrm{CF} / \mathrm{mL}+\mathrm{Uji}$ tantang bakteri A.hydrophila. Perlakuan D yaitu pakan buatan dengan tambahan bakteri kandidat probiotik kepadatan $10^{9} \mathrm{CFU} / \mathrm{mL}+$ Uji tantang bakteri A.hydrophila.

\section{Persiapan Wadah dan Kultur Nila}

Media pemeliharaan dalam penelitian ini menggunakan air tawar, berasal dari air pam yang telah diendapkan terlebih dahulu pada bak tandon selama satu minggu dan telah disterilkan. Volume air yang digunakan adalah $10 \mathrm{~L}$ untuk masing-masing akuarium. Wadah yang digunakan dalam penelitian ini adalah akuarium dengan ukuran $40 \mathrm{~cm} x$ $30 \mathrm{~cm}$ x 40cm dengan kapasitas $48 \mathrm{~L}$ air yang diisi $10 \mathrm{~L}$ air. Jumlah akuarium yang digunakan untuk penelitian ini sebanyak 12 buah. Penempatan akuarium secara acak. Tahap pelaksanaan masa pemeliharaan dengan seleksi ikan untuk mendapatkan berat yang seragam dilakukan sebelum pengadaptasian. Ikan yang digunakan dalam penelitian ini adalah ikan nila (O.niloticus) dengan bobot rata-rata 14,43 $\pm 0,11$ g yang berasal dari Unit Pembenihan Rakyat pembudidaya Mina Muncul (Muncul, Ambarawa, Semarang) dengan padat tebar 1 ekor/L. Jumlah ikan setiap akuarium adalah 10 ekor, dan jumlah total ikan yang digunakan dalam penelitian adalah 120 ekor.

Tahap pelaksanaan terdiri dari uji in vitro, uji pendahuluan, masa pemeliharaan, dan uji tantang. Uji in vitro bertujuan untuk mengetahui berapa besar potensi B.methylotrophicus dapat menghambat pertumbuhan A.hydrophila. uji zona hambat dilakukan dengan melihat ada tidaknya zona hambat/zona bening di sekitar kertas cakram dan diukur diameter zona hambat tersebut Haditomo et.al. (2016). Uji daya hambat menggunakan kertas cakram yang sebelumnya telah direndam pada konsentrasi tertentu bakteri kandidat probiotik. Pengamatan hasil dapat dilakukan 1 x 24 jam dari penanaman kertas cakram. Uji pendahuluan dilakukan melalui aplikasi bakteri kandidat probiotik pada media budidaya ikan nila yang terdapat bakteri patogen A.hydrophila $10^{4} \mathrm{CFU} / \mathrm{mL}$ dan diamati respon ikan nila selama 14 hari masa pemeliharaan. Konsentrasi bakteri kandidat probiotik yang diujikan berbeda-beda yaitu $10^{3} 10^{4} 10^{5} \mathrm{CFU} / \mathrm{mL}$ sebanyak 5 perlakuan dengan 3 kali ulangan, yang terdapat 2 perlakuan kontrol (positif dan negatif). Setiap satuan perlakuan membutuhkan 20 ekor ikan (kepadatan 2 ekor/L. Parameter yang diamati adalah gejala klinis, kelulushidupan, jumlah kepadatan bakteri pada media budidaya (Haditomo et al., 2016). Hasil uji pendahuluan belum mendapatan hasil yang 
terbaik namun hasil kelulushidupan terbaik adalah kepadatan CBL20 10 5 CFU/mL dengan kepadatan A.hydrophila $10^{4} \mathrm{CFU} / \mathrm{mL}$ (Haditomo et al., 2017). Hasil kepadatan bakteri kandidat probiotik B.methylotrophicus $10^{5} \mathrm{CFU} / \mathrm{mL}$ tersebut digunakan sebagai dasar pemilihan perlakuan dan juga menggunakan hasil dari penelitian Agustina et.al. (2018) pada kepadatan $10^{7}$ dan $10^{9} \mathrm{CFU} / \mathrm{mL}$ pada media air mendapatkan kelulushidupan tertinggi yaitu $50,00 \%$ dan $56,67 \%$. Uji tantang dilakukan setelah pemberian pakan uji selama 7 hari pada masing-masing perlakuan dengan pemeliharaan selama 14 hari dengan total waktu pemeliharaan penelitian tersebut yaitu 21 hari. Kepadatan bakteri patogen untuk uji tantang $10^{2} \mathrm{CFU} / \mathrm{ml}$ didasarkan pada hasil penelitian Agustina et.al. (2018) yang dengan metode uji tantang yang sama yaitu diberikan pada media air mendapatkan hasil kelulushidupan tertinggi yaitu 56,67\%. Sehingga dengan kepadatan bakteri A.hydrophila $10^{2} \mathrm{CFU} / \mathrm{mLdianggap}$ cukup lethal.

\section{Pengambilan Data dan Analisa Statistika}

Variabel yang diamati adalah sebagai berikut yaitu Efisiensi Pemanfaatan Pakan (EPP), menurut Tacon (1987), perhitungan efisiensi pemanfaatan pakan menggunakan rumus: EPP = (Jumlah pakan yang diberikan/ penambahan bobot ikan yang dihasilkan) x 100\%, dimana EPP : Efisiensi pemanfaatan pakan (\%), Wt : Bobot total hewan uji pada akhir penelitian (gr), Wo : Bobot total hewan uji pada awal penelitian (gr), F : Jumlah pakan yang dikonsumsi selama penelitian (gr). Rasio Konversi Pakan (FCR). Perhitungan nilai rasio konversi pakan dengan menggunakan rumus Tacon (1987), sebagai berikut: FCR $=\left(\mathrm{Wt}_{0}\right) / \mathrm{F}$, dimana FCR : Feed Conversation Ratio, Wt : Bobot total hewan uji pada akhir penelitian (gr), $\mathrm{W}_{0}$ : Bobot total hewan uji pada awal penelitian (gr), F : Jumlah pakan yang dikonsumsi selama penelitian (gr). Laju Pertumbuhan Relatif (Relative Growth Rate / RGR). Menurut Takeuchi (1988) laju pertumbuhan relatif (RGR) ikan dihitung dengan menggunakan rumus: $\mathrm{RGR}=\left(\mathrm{Wt}-\mathrm{W}_{0}\right) /\left(\mathrm{W}_{0} \mathrm{xt}\right)$ $\mathrm{x} 100 \%$, dimana $\mathrm{W}_{\mathrm{t}}=$ Bobot biomassa ikan uji pada akhir pemeliharaan $(\mathrm{g}), \mathrm{W}_{\mathrm{o}}=$ Bobot biomassa ikan uji pada awal pemeliharaan (g), $\mathrm{t}=$ Waktu pemeliharaan (hari). Kelulushidupan (Survival Rate/SR), menurut Effendi (1997), perhitungan kelangsungan hidup menggunakan rumus: $\mathrm{SR}=\left(\mathrm{Nt} / \mathrm{N}_{0}\right)$ x $100 \%$, dimana $\mathrm{SR}$ : Tingkat Kelangsungan Hidup (\%), $\mathrm{N}_{\mathrm{t}}$ : Jumlah individu pada akhir penelitian (ekor), $\mathrm{N}_{0}$ : Jumlah individu pada awal penelitian (ekor).

Data gejala klinis diamati secara visual setelah ikan nila dimasukkan ke dalam media pemeliharaan. Parameter pengamatan yaitu perubahan tingkah laku dan morfologi yang terjadi pada ikan nila. Pengamatan ini dilakukan setiap hari selama masa pemeliharaan 14 hari secara visual. Pengamatan profil darah ikan nila dilakukan sebelum dan setelah infeksi bakteri $A$. hydrophila. Pengambilan data parameter imunitas dengan mengambil sampel darah dilakukan pada hari ke-0, 8,12,16,20 pasca infeksi. Pengambilan darah dilakukan dengan menggunakan spuit suntik $1 \mathrm{~mL}$ yang diarahkan ke bagian arteri caudalis. Metode perhitungan total leukosit dan eritrosit mengacu pada metode Blaxhall dan Daisley (1973), menggunakan larutan Turk's untuk leukosit dan Hayem untuk eritrosit. Perhitungan menggunakan rumus $:$ Total Eritrosit $=$ Jumlah sel terhitung x $10^{4} \mathrm{sel} / \mathrm{mm}^{3}$; Total Leukosit $=$ Jumlah sel terhitung x $50 \mathrm{sel} / \mathrm{mm}^{3}$. Prosedur perhitungan kadar hemoglobin mengacu pada metode Sahli. Kadar hemoglobin dinyatakan dalam g/dl. Kadar hematokrit dinyatakan dengan \% volume darah dengan rumus : Kadar hematokrit $(\%)=$ a x b x 100\%. Kualitas air, parameter kualitas air yang diukur meliputi DO, $\mathrm{pH}$, dan suhu. Pengamatan suhu dilakukan setiap hari diwaktu pagi, sedangkan pengamatan DO dan $\mathrm{pH}$ dilakukan setiap satu minggu sekali diwaktu sore. Pengukuran pH dilakukan dengan menggunakan $\mathrm{pH}$ meter dengan cara mencelupkan $\mathrm{pH}$ meter pada wadah pemeliharaan dan melihat hasilnya. Pengukuran oksigen terlarut (DO) menggunakan DO meter dengan mencelupkan ujung alat indikator (probe) ke dalam air kemudian menunggu hingga konstan dan mencatat nilainya.

Analisis data uji dilakukan dengan dua metode yaitu analisis statistik pada selang kepercayaan 95\% (alpha $=0,05)$ dan analisis deskriptif. Perangkat lunak Microsoft Excel digunakan untuk analisis statistik. Data-data tersebut dilakukan uji normalitas, homogenitas, dan aditifitas untuk memenuhi kaidah normal, homogen, dan aditif, kemudian uji analisis sidik ragam (ANOVA), apabila ditemukan pengaruh yang nyata maka dilanjutkan uji lanjutan dengan Duncan's multiple range test (DMRT). Analisis statistik digunakan untuk analisis data efisiensi pemanfaatan pakan, pertumbuhan, rasio konversi pakan, tingkat kelangsungan hidup, sedangkan analisis deskriptif digunakan untuk data tingkat konsumsi pakan, profil darah, gejala klinis dan kualitas air.

\section{HASIL}

\section{a. Performa Pertumbuhan}

Variabel yang diamati adalah sebagai berikut yaitu Efisiensi Pemanfaatan Pakan (EPP), Rasio Konversi Pakan (FCR), Laju Pertumbuhan Relatif (Relative Growth Rate / RGR), dan Kelulushidupan (Survival Rate/SR). Hasil penelitian menunjukkan bahwa penambahan bakteri kandidat probiotik B.methylotrophicus pada pakan buatan memiliki pengaruh yang nyata $(\mathrm{P}<0.05)$ terhadap laju pertumbuhan relatif $(\mathrm{RGR})$ dan kelulushidupan $(\mathrm{SR})$ ikan nila (O.niloticus), dan tidak memiliki pengaruh yang nyata $(\mathrm{P}>0.05)$ terhadap efisiensi pemanfaatan pakan $(\mathrm{EPP})$ dan rasio konversi pakan (FCR) ikan nila (O.niloticus) serta tidak memengaruhi kualitas air media pemeliharaan. Hasil penelitian nilai EPP, FCR, RGR, dan SR melalui penambahan bakteri kandidat probiotik pada pakan buatan ikan nila (O.niloticus) dapat dilihat pada Tabel 1. 
Tabel 1. Nilai Rata-rata EPP, FCR, RGR, dan SR pada Ikan Nila (O.niloticus) Selama Pemeliharaan.

\begin{tabular}{ccccc}
\hline \multirow{2}{*}{ Perlakuan } & \multicolumn{4}{c}{ Variabel yang diamati } \\
\cline { 2 - 5 } & EPP $(\%)$ & FCR & RGR $(\% /$ hari $)$ & SR $(\%)$ \\
\hline A & $8.10 \pm 4,60^{\mathrm{a}}$ & $4,04 \pm 1,88^{\mathrm{a}}$ & $0,86 \pm 0,43^{\mathrm{a}}$ & $13,33 \pm 5,77^{\mathrm{a}}$ \\
B & $9,13 \pm 0,70^{\mathrm{a}}$ & $3,20 \pm 1,37^{\mathrm{a}}$ & $1,08 \pm 0,15^{\mathrm{a}}$ & $20,00 \pm 0,00^{\mathrm{a}}$ \\
C & $10,78 \pm 1,02^{\mathrm{a}}$ & $2,01 \pm 0,29^{\mathrm{a}}$ & $1,72 \pm 0,14^{\mathrm{b}}$ & $36,67 \pm 5,77^{\mathrm{b}}$ \\
D & $10,44 \pm 2,83^{\mathrm{a}}$ & $3,63 \pm 2,34^{\mathrm{a}}$ & $1,38 \pm 0,36^{\mathrm{ab}}$ & $30,00 \pm 0,00^{\mathrm{b}}$ \\
\hline
\end{tabular}

Keterangan: Huruf superscript yang berbeda menunjukan perbedaan yang nyata $(\mathrm{P}<0.05)$

Hasil uji menunjukkan bahwa rerata efisiensi pemanfaatan pakan (EPP) tertinggi hingga terendah berturut-turut

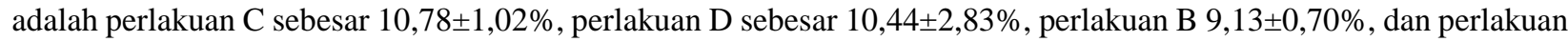
A sebesar $8.10 \pm 4,60 \%$. Rata-rata nilai FCR pada masing-masing perlakuan dari yang tertinggi hingga yang terendah

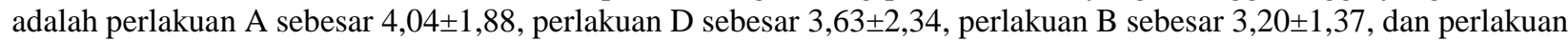
C $02,01 \pm 0,29$. Rerata laju pertumbuhan relatif (RGR) dari tertinggi hingga terendah yaitu perlakuan C $1,72 \pm 0,14 \%$ /hari, perlakuan D $1,38 \pm 0,36 \%$ /hari, perlakuan B $1,08 \pm 0,15 \%$ /hari, dan perlakuan A sebesar $0,86 \pm 0,43 \%$ /hari. Rata-rata nilai SR pada masing-masing perlakuan dari yang tertinggi hingga yang terendah adalah

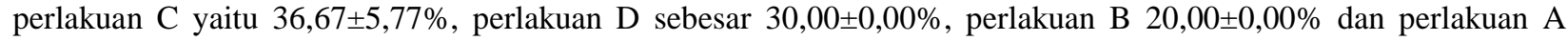

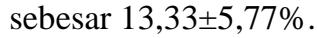

\section{b. Tingkat Konsumsi Pakan}

Secara umum pada semua perlakuan menghasilkan gambaran pola pergerakan grafik/ trend grafik yang naik turun selama 21 hari pemeliharaan. Pada awal 7 hari masa pemeliharaan yaitu pemberian pakan uji sebelum dilakukan uji tantang/ pra uji tantang menunjukkan pola grafik yang naik turun, dengan nilai tertinggi pada perlakuan $\mathrm{C}$. Berdasarkan grafik tersebut selama 21 hari pemeliharaan nilai tingkat konsumsi pakan tertinggi ada pada perlakuan B pada hari ke 17 dan terendah ada pada perlakuan A pada hari ke 20. Sedangkan nilai tertinggi perlakuan C dan D ada pada hari ke 19 pasca uji tantang.

\section{c. Gejala Klinis Ikan dan Profil Darah}

Gejala klinis ikan nila pada semua perlakuan menunjukkan terjadi perubahan tingkah laku. Selama 7 hari awal masa pemeliharaan diberikan perlakuan pemberian pakan uji sebelum dilakukan uji tantang dan memberikan hasil berupa ikan masih dalam keadaan stabil dan memiliki respon pakan cepat. Gejala klinis pada semua perlakuan sebagian besar menunjukkan hasil berupa pergerakan berenang pasif, tidak stabil, memiliki respon pakan yang lambat, serta ditandai dengan adanya sirip ekor atau punggung geripis dan sisik lepas pasca dilakukan uji tantang pada hari ke 8 masa pemeliharaan. Perbedaan pada perlakuan yang terlihat dari hasil pengamatan gejala klinis adalah antara perlakuan A dan B yang pada hari ke 2 terlihat memiliki respons pakan yang lambat dan pergerakan yang pasif dengan perlakuan $\mathrm{C}$ dan D yang sebagian besar masih memiliki respons pakan yang cepat. Selain itu juga pada perlakuan A dan B hari ke 17 sebagian besar ikan sudah tidak merespon pakan atau sangat pasif sedangkan pada perlakuan C dan D sebagian masih merespon pakan walaupun secara pasif.

Hasil pengukuran profil darah (leukosit, eritrosit, hematokrit, hemoglobin) pada hari ke-0, setelah pemberian 7 hari bakteri kandidat probiotik, dan pasca uji tantang hari ke-8,12,16,20 tersaji pada Gambar 1. 


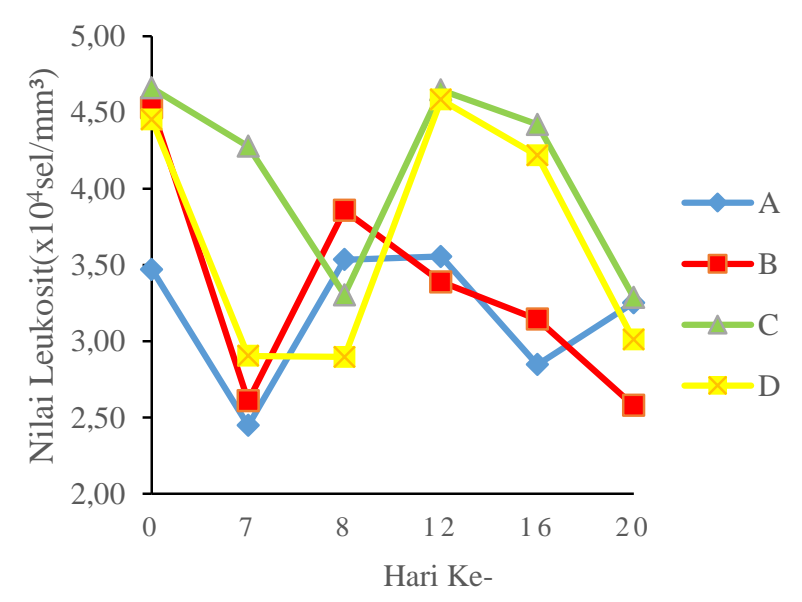

(a)

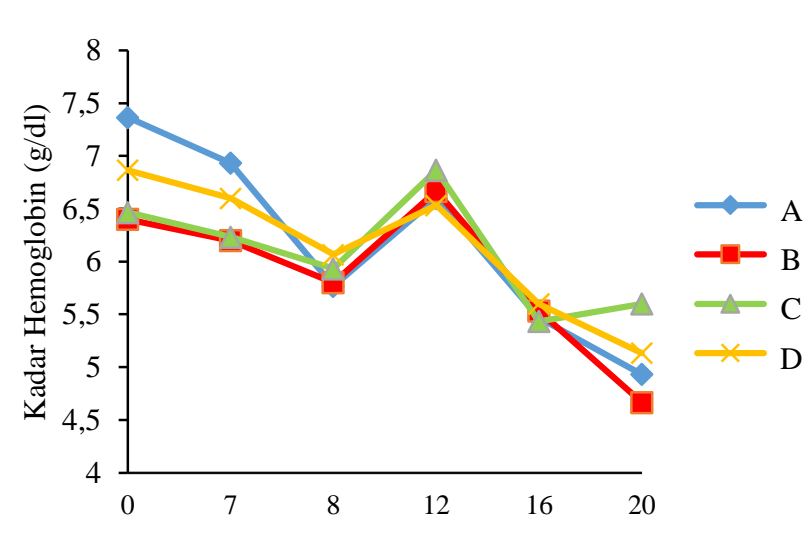

Hari Ke-

(d)

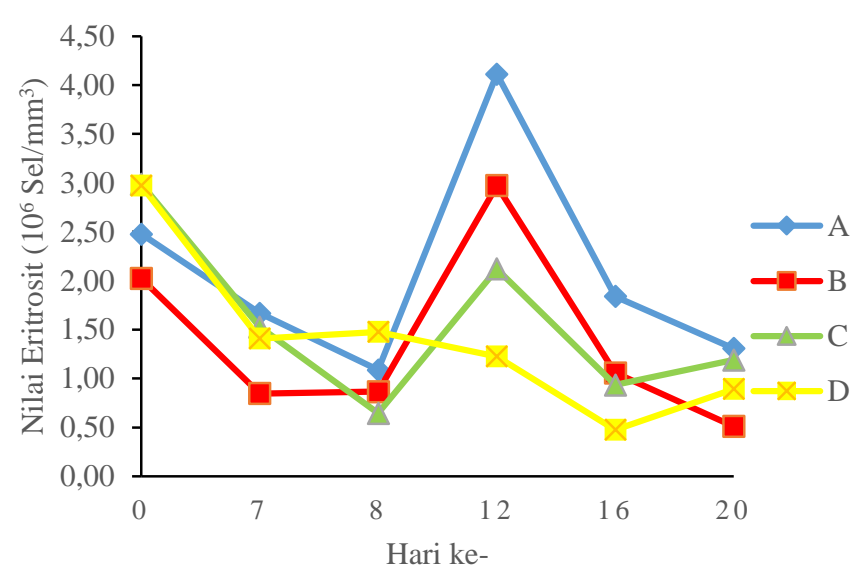

(b)

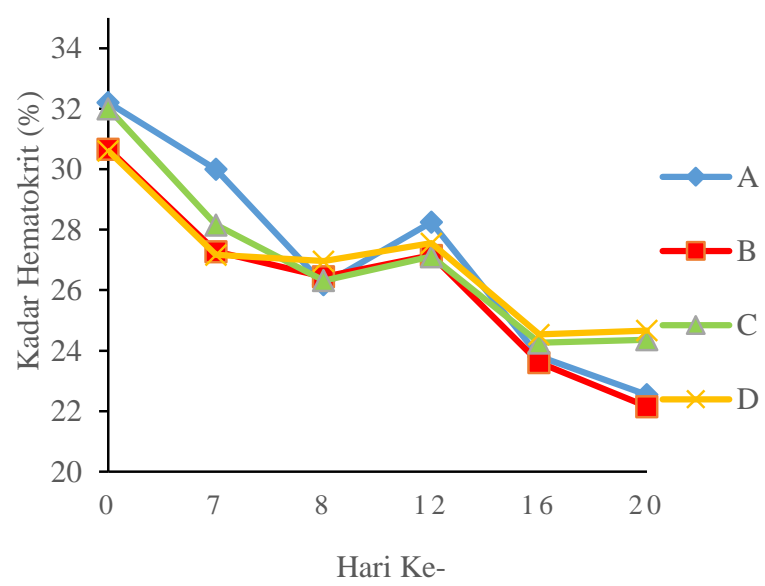

(c)

Gambar 1. Pola Grafik Profil Darah Dari

Sebelum Dan Sesudah Uji Tantang Dengan Bakteri Patogenik A.Hydrophila. (a) nilai leukosit; (b) nilai eritrosit; (c) nilai hematokrit; (d) nilai hemoglobin

Keterangan : Hari ke-7: Setelah pemberian 7 hari bakteri kandidat probiotik

Hari ke- 8,12,16,20 : Pasca uji tantang

Nilai rerata total leukosit tertinggi pada hari ke 12 pasca uji tantang ada pada perlakuan $\mathrm{C}$ yaitu 46.500 $\mathrm{sel} / \mathrm{mm}^{3}$, dan rerata terendah pada hari ke 7 pasca pemberian pakan uji yaitu pada perlakuan A sebesar $24.500 \mathrm{sel} / \mathrm{mm}^{3}$ (dalam kisaran normal). Nilai rerata total eritrosit tertinggi pada hari ke 12 pasca uji tantang ada pada perlakuan A yaitu 4,11 x $10^{6} \mathrm{sel} / \mathrm{mm}^{3}$ dan berada diatas kisaran normal untuk ikan nila, serta terendah pada hari ke 16 pasca uji tantang yaitu pada perlakuan D sebesar $0,25 \times 10^{6} \mathrm{sel} / \mathrm{mm}^{3}$. Nilai rerata kadar hematokrit tertinggi pada hari ke 0 pada perlakuan A yaitu 33\% (berada pada kisaran normal), nilai rerata terendah pada hari ke 20 pasca uji tantang yaitu pada perlakuan B sebesar 22,15\%. Nilai rerata kadar hemoglobin tertinggi pada hari ke 0 pada perlakuan A yaitu 7,37 g/dl dan terendah pada hari ke 20 pasca uji tantang yaitu pada perlakuan B sebesar 4,67 g/dl.

\section{PEMBAHASAN}

\section{Performa Pertumbuhan}

Berdasarkan hasil analisis ragam menunjukkan perlakuan penambahan probiotik tidak memberi pengaruh nyata terhadap EPP, namun nilai tertinggi rerata efisiensi pemanfaatan pakan pada perlakuan $\mathrm{C}$ dengan penambahan $10^{7}$ $\mathrm{CFU} / \mathrm{mL}$ pada pakan, lebih tinggi dibandingkan dengan perlakuan lain. Hal tersebut diduga karena dengan penambahan bakteri kandidat probiotik mampu menghasilkan enzim-enzim yang dapat membantu ikan nila (O.niloticus) untuk mencerna pakan dengan baik. Hal tersebut diperkuat Putra (2010), bakteri yang terdapat dalam 
probiotik menghasilkan enzim seperti amilase, protease, lipase dan selulose yang membantu menghidrolisis nutrisi pakan yang tersimpan (molekul kompleks), seperti karbohidrat, protein dan lemak menjadi molekul yang lebih sederhana sehingga mempermudah proses pencernaan dan penyerapan pakan dalam saluran pencernaan ikan. Diduga pakan dengan campuran probiotik memiliki kualitas yang lebih baik dibandingkan dengan pakan tanpa probiotik, semakin tinggi nilai EPP berarti kualitas pakan tersebut semakin baik (Wardika et al., 2014).

Nilai terendah rerata efisiensi pemanfaatan pakan pada perlakuan A (0 CFU/mL) tanpa penambahan pada pakan, yaitu 8.10 $\pm 4,60$. Sainah et.al. (2016) menyatakan tidak adanya penambahan bakteri probiotik pada pakan, berakibat tidak adanya pertambahan bakteri yang dapat membantu proses pencernaan, sehingga pakan tidak tercerna dengan optimal. Perlakuan D $\left(10^{9} \mathrm{CFU} / \mathrm{mL}\right)$ sebagai perlakuan dengan kepadatan bakteri kandidat probiotik tertinggi tidak memberikan nilai rerata efisiensi pemanfaatan pakan lebih baik dibandingkan perlakuan lain. Hal tersebut diperkuat oleh Sainah et.al. (2016) nilai pemanfaatan pakan yang rendah pada dosis probiotik yang tinggi pada pakan dapat diakibatkan karena terlalu tingginya populasi bakteri sehingga menyebabkan terjadinya persaingan antar bakteri untuk memperoleh nutrisi.

Hasil uji analisis ragam menunjukkan bahwa penambahan bakteri kandidat probiotik pada pakan tidak berpengaruh yang nyata terhadap rasio konversi pakan (FCR) ikan nila. Nilai tertinggi rerata rasio konversi pakan pada perlakuan A yaitu 4,04 1,88 dengan penambahan $0 \mathrm{CFU} / \mathrm{mL}$ pada pakan, lebih tinggi dibandingkan dengan perlakuan lain. Nilai tersebut berbanding lurus dengan pertumbuhan yang rendah pula sehingga dapat dinilai bahwa dengan kepadatan $0 \mathrm{CFU} / \mathrm{mL}$ pada pakan tidak berpengaruh secara signifikan terhadap pertumbuhan karena FCR menunjukkan nilai efisiensi pakan yang digunakan oleh ikan untuk pertumbuhan. Menurut Ardita et.al. (2015) pada dasarnya, probiotik ditambahkan kedalam pakan digunakan untuk memperlancar sistem pencernaan pada ikan agar pakan yang dimakan lebih efisien. Sehingga dengan sistem pencernaan dari ikan nila tersebut dalam kondisi maksimal, setelah diberikan probiotik akan berpengaruh terhadap pencernaan ikan dan pertumbuhan ikan.

Nilai terendah rerata rasio konversi pakan dibanding perlakuan lain yaitu pada perlakuan $\mathrm{C}\left(10^{7} \mathrm{CFU} / \mathrm{mL}\right)$

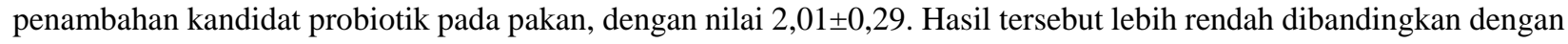
perlakuan lain yang berarti memiliki nilai FCR yang bagus. Menurut Ihsanudin et.al. (2014), nilai FCR yang paling kecil yaitu dapat diartikan mempunyai nilai FCR yang paling bagus dikarenakan pemanfaatan pakan untuk pertumbuhan sangat efisien, hal ini disebabkan pola nafsu makan ikan yang relatif besar sehingga kebutuhan pakan yang digunakan untuk pertumbuhan sangatlah terpenuhi. Nilai Food Convertion Ratio (FCR) cukup baik berkisar 0.81.6. Hal tersebut diperkuat oleh Agustin et.al. (2014), adanya bakteri probiotik dalam pakan yang kemudian masuk kedalam saluran pencernaan dapat menekan bakteri patogen yang ada dalam usus sehingga membantu proses penyerapan makanan lebih cepat dan memperlancar sistem pencernaan pada ikan (Ardita et al., 2015).

Hasil analisis ragam menunjukkan bahwa penambahan bakteri kandidat probiotik pada pakan buatan dengan kepadatan berbeda berpengaruh nyata terhadap laju pertumbuhan relatif (RGR) ikan nila (O.niloticus). Hasil uji menunjukkan bahwa rerata laju pertumbuhan relatif terbaik pada ikan nila (O.niloticus) adalah pada perlakuan $\mathrm{C}$ yaitu kepadatan bakteri $10^{7} \mathrm{CFU} / \mathrm{mL}$ yang lebih tinggi dibanding perlakuan tanpa penambahan bakteri kandidat probiotik pada pakan buatan. Hal tersebut dapat diduga karena dengan kepadatan tersebut merupakan kepadatan yang sesuai untuk dimanfaatkan sebagai energi pertumbuhan dibanding dengan kepadatan pada perlakuan lain. Menurut Wardika et.al. (2014) diduga energi pakan yang diberikan cukup sehingga kebutuhan energi untuk metabolisme cukup dan dapat digunakan untuk tumbuh. Lebih lanjut penambahan probiotik pada pakan juga turut membantu proses pencernaan dengan baik sehingga mampu digunakan ikan untuk tumbuh dengan baik.

Perlakuan D (10 $\mathrm{CFU} / \mathrm{mL})$ sebagai perlakuan dengan kepadatan bakteri kandidat probiotik tertinggi tidak memberikan nilai rerata laju pertumbuhan relatif (RGR) lebih tinggi dibandingkan perlakuan $\mathrm{C}$ dengan kepadatan bakteri lebih rendah yaitu $10^{7} \mathrm{CFU} / \mathrm{mL}$. Hal tersebut dapat dikarenakan dengan tingginya bakteri pada pakan mengakibatkan pula tingginya bakteri pada pencernaan sehingga terjadi persaingan untuk memperoleh nutrisi sehingga dalam membantu proses pencernaan tidak optimal dan selanjutnya pertumbuhan juga kurang optimal. Hal tersebut diperkuat oleh Sainah et.al. (2016) nilai pemanfaatan pakan yang rendah pada dosis probiotik yang tinggi pada pakan dapat diakibatkan karena tingginya populasi bakteri sehingga menyebabkan persaingan antar bakteri untuk memperoleh nutrisi sehingga kerja bakteri dalam membantu proses pencernaan pakan kurang maksimal.

Hasil pada semua perlakuan secara umum menghasilkan gambaran pola pergerakan grafik/ trend grafik yang naik turun selama 21 hari pemeliharaan. Tingkat konsumsi pakan yang tinggi dan rendah pada perlakuan dapat mengindikasikan ikan dalam keadaan baik untuk mengonsumsi pakan dan memanfaatkan untuk proses metabolisme. Beberapa faktor ikan mampu mengonsumsi pakan dengan baik adalah nilai nutrisi pakan, serta frekuensi pemberiannya. Menurut Royan et.al. (2014), menyatakan efisiensi yang terbaik menunjukkan tingkat konsumsi pakan yang dimakan lebih sedikit dibanding perlakuan lainnya. Jumlah pakan yang mampu dikonsumsi ikan setiap harinya merupakan salah satu faktor yang mempengaruhi potensi ikan untuk tumbuh secara maksimal yang berarti, pengurangan jumlah pakan yang dikonsumsi secara periodik mampu meningkatkan efisiensi pakan.

Tingkat konsumsi pakan dapat mengindikasikan ikan dalam keadaan sehat dan kondisi nafsu makan yang baik atau tidak, yang berkaitan dengan profil darah. Pada perlakuan yang memiliki profil darah total eritrosit rendah mampu 
mempengaruhi metabolisme ikan uji. Hal tersebut diperkuat Alamanda et.al. (2016) bahwa anemia berdampak pada pertumbuhan ikan, karena rendahnya jumlah eritrosit mengakibatkan suplai makanan ke sel dan jaringan berkurang sehingga proses metabolisme ikan terhambat. Menurut Royan et.al. (2014) tingkat konsumsi pakan dapat dijadikan data pendukung untuk memperkuat dari data profil darah ikan nila. Ikan nila yang mengalami stres dan daya tahan tubuh yang buruk ditinjau dari data profil darah menujukan konsumsi pakan yang lebih sedikit. Persentase hematokrit yang mengalami kenaikan karena ikan mulai makan seperti aktivitas normal.

Hasil uji menunjukkan bahwa rerata kelulushidupan terbaik pada ikan nila (O.niloticus) adalah pada perlakuan $\mathrm{C}$ yaitu kepadatan bakteri $10^{7} \mathrm{CFU} / \mathrm{mL}$. Perlakuan $\mathrm{C}$ tidak berbeda nyata dengan perlakuan $\mathrm{D}$, namun berbeda sangat nyata terhadap perlakuan B dan perlakuan A. Hal ini diduga karena dengan adanya penambahan bakteri probiotik dalam pakan, bakteri probiotik tersebut mampu menekan pertumbuhan bakteri patogen yang dapat menyebabkan kematian pada ikan (Sainah et al., 2016).

Hasil uji analisis ragam menunjukkan bahwa penambahan bakteri kandidat probiotik pada pakan memberikan pengaruh yang nyata $(\mathrm{P}<0,05)$ terhadap nilai kelulushidupan $(\mathrm{SR})$ ikan nila. Nilai kelulushidupan yang rendah pada perlakuan A tidak ditambahkan probiotik, sehingga populasi bakteri yang dapat mengoksidasi bahan organik sedikit. Peningkatan bahan organik pada media akan menjadi racun dalam air pemeliharaan. Dampaknya akan memicu timbulnya penyakit dan kurangnya nafsu makan sehingga berakibat laju pertumbuhan rendah (Wardika et al., 2014).

\section{Gejala Klinis}

Berdasarkan hasil gejala klinis yang teramati pada ikan nila, terdapat perubahan tingkah laku. Sebelum dilakukan uji tantang $A$. hydrophila yaitu pada hari ke 1 hingga hari ke 7 ikan uji teramati dalam kondisi sehat dengan nafsu makan yang baik dan gerakan berenang yang normal. Diduga pemberian probiotik mampu memberikan sistem imun sebelum uji tantang dan berguna bagi optimalisasi kecernaan pakan. Menurut Sukenda et.al. (2016) pemberian probiotik dapat meningkatkan respons imun nonspesifik dan meningkatkan resistensi ikan terhadap serangan patogen. Lebih lanjut, Lusiastuti et.al. (2016) menjelaskan Bacillus mempunyai kemampuan sebagai immunostimulan dan dapat meningkatkan kecernaan pakan karena mempunyai beberapa enzim.

Hasil gejala klinis perlakuan A dan B hari ke 17 sebagian besar ikan sudah tidak merespon pakan atau sangat pasif serta perlakuan A (0 CFU/mL) memiliki gejala morfologi lebih. Abumourad et al. (2014) yang menyatakan bahwa pemberian probiotik pada ikan O.niloticus melalui pakan dapat meningkatkan laju pertumbuhan ikan tersebut dan menunjukkan perubahan histopatologi yang lebih ringan dibandingkan kontrol setelah diuji tantang dengan $A$. hydrophila. Hal tersebut diperkuat oleh Lusiastuti et.al. (2016) pada perlakuan kontrol tanpa pemberian probiotik pada pakan menunjukkan derajat kerusakan organ, diduga karena populasi A. hydrophila yang tinggi dan tidak adanya bakteri probiotik yang mampu menurunkan jumlah patogen $A$. hydrophila.

\section{Profil Darah}

Hasil pengamatan nilai total leukosit pada hari ke 0 berada pada kisaran normal pada semua perlakuan yaitu kemudian mengalami penurunan pada hari ke 7 pasca pemberian pakan uji pada semua perlakuan namun. Royan et.al. (2014) menjelaskan bahwa ikan nila dengan panjang rata-rata 13,18 $\pm 0,94 \mathrm{~cm}$ mendapatkan hasil penelitian rerata total leukosit ikan nila antara $0,36 \times 104 \mathrm{sel} / \mathrm{mm}^{3}-3,14 \times 104 \mathrm{sel} / \mathrm{mm}^{3}$ adalah tergolong hampir sama dan rendah dibawah kisaran normal leukosit ikan nila $20.000 \mathrm{sel} / \mathrm{mm}^{3}-150.000 \mathrm{sel} / \mathrm{mm}^{3}$ (Lagler et al.,1977).

Penurunan terjadi pada hari ke 7 pasca pemberian pakan uji (pra uji tantang) dan hari ke 20 pasca uji tantang. Hal tersebut diperkuat oleh Ulkhaq et al., (2014) bahwa penurunan leukosit sampai akhir penelitian diduga karena populasi A.hydrophila dalam air sudah terkontrol sehingga tidak memengaruhi kondisi sistem imun ikan. Penurunan jumlah leukosit dapat berdampak negatif pada ikan karena kekebalan tubuh dapat menurun (Matofani et al.,2013).

Hasil pengamatan nilai total eritrosit pada hari ke 0 berada pada kisaran normal pada semua perlakuan, kemudian mengalami penurunan pada hari ke 7 pasca pemberian pakan. Adanya penurunan total eritrosit tersebut disebabkan oleh salah satunya serangan penyakit pasca dilakukan uji tantang sebagai bentuk perlawanan terhadap patogen. Hal tersebut diperkuat Matofani et.al. (2013) bahwa eritrosit mengalami penurunan diduga karena terjadi fagositosis bakteri yang masuk. Proses tersebut membutuhkan oksigen sehingga terjadi penurunan eritrosit.

Kenaikan total eritrosit terjadi pada hari ke 12 pasca uji tantang pada pada semua perlakuan, terkecuali perlakuan D dan hari ke 20 pada perlakuan $\mathrm{C}\left(10^{7} \mathrm{CFU} / \mathrm{ml}\right)$ dan $\mathrm{D}\left(10^{9} \mathrm{CFU} / \mathrm{ml}\right)$. Terjadinya kenaikan jumlah total eritrosit dapat diduga karena ikan mengalami stres saat pengambilan darah. Menurut Zuhrawati (2014) untuk mengurangi keadaan stres maka ikan akan menyesuaikan kondisi fisiologisnya dengan meningkatkan jumlah eritrosit dalam sirkulasi. Keadaan stres mampu memberi dampak buruk bagi ikan, menurut Bangsa et.al. (2015) stres memeengaruhi kinerja dan kesehatan ikan berupa gangguan fungsi sel darah salah satunya yaitu eritrosit.

Hasil pengamatan nilai kadar hematokrit pada hari ke 0 berada pada kisaran normal pada semua perlakuan yaitu berkisar 30,60\% - 32,20\%, kemudian mengalami penurunan pada hari ke 7 pasca pemberian pakan uji pada semua perlakuan dan berada dibawah kisaran normal pada perlakuan B $\left(10^{5} \mathrm{CFU} / \mathrm{ml}\right)$ dan D $\left(10^{9} \mathrm{CFU} / \mathrm{ml}\right)$. Menurut Hardi et.al. (2011) rataan kadar hematokrit ikan nila normal berkisar 27,3-37,8\%. Kisaran normal pada ikan dapat diduga 
merupakan pengauh pemberian bakteri kandidat probiotik, menurut Sukenda et.al. (2016) pemberian probiotik mampu menstabilkan kadar hematokrit pada benih yang terinfeksi A. hydrophila, meningkatkan respons imun nonspesifik dan resistensi patogen. Peningkatan kadar hematokrit terjadi pada hari ke 12 pasca uji tantang pada semua perlakuan. Hardi et.al. (2011) dalam penelitian faktor penyebab stres seperti lingkungan dan penanganan diminimalisir sehingga peningkatan hematokrit dapat dipastikan karena adanya infeksi patogen.

Hasil pengamatan nilai kadar hemoglobin pada hari ke 0 berada pada kisaran normal pada semua perlakuan yaitu berkisar $6,40-7,37 \mathrm{~g} / \mathrm{dl}$, kemudian mengalami penurunan pada hari ke 7 pasca pemberian pakan uji pada semua perlakuan dan tiap perlakuan berada dibawah kisaran normal dan terus turun pada hari ke 8 pasca uji tantang. Menurut Hardi et.al. (2011) kadar rata-rata Hb ikan nila normal berkisar 6 - 11,01 (g\%). Penurunan kadar hemoglobin terus terjadi dari hari ke 0 hingga ke 8 pasca uji tantang. Hal tersebut dapat terjadi diduga ikan mengalami infeksi dan melakukan mekanisme pertahanan terhadap kondisi tubuh. Diperkuat oleh Fauziah et.al. (2013), bahwa terjadi penurunan kadar hemoglobin setelah infeksi bakteri dalam darah ikan nila, dan selanjutnya darah akan melakukan mekanisme fagositosis sebagai bentuk perlawanan terhadap bakteri patogen.

\section{KESIMPULAN DAN SARAN}

\section{Kesimpulan}

1. Penambahan bakteri kandidat probiotik B.methylotrophicus pada pakan buatan berpengaruh terhadap dinamika profil darah ikan nila (O.niloticus) yang diuji tantang dengan bakteri patogen A.hydrophila dengan gejala klinis ikan menunjukkan adanya infeksi dari lingkungan disebabkan oleh adanya serangan bakteri;

2. Penambahan bakteri kandidat probiotik B.methylotrophicus pada pakan buatan tidak berpengaruh signifikan terhadap performa pertumbuhan ikan nila (O.niloticus);

3. Kepadatan bateri B.methylotrophicus terbaik untuk menghambat A.hydrophila secara in vitro adalah $10^{9} \mathrm{CFU} / \mathrm{mL}$ namun secara in vivo belum diperoleh dosis yang sesuai.

\section{Saran}

Saran yang dapat diberikan pada penelitian ini adalah perlunya penelitian lanjut mengenai penambahan bakteri kandidat probiotik B.methylotrophicus pada pakan buatan untuk mengetahui pengaruh terbaik untuk performa pertumbuhan, serta peningkatan kepadatan bakteri kandidat probiotik B.methylotrophicus pada pakan buatan untuk memperoleh hasil yang lebih optimal.

\section{Ucapan Terima Kasih}

Penelitian ini merupakan bagian dari payung penelitian screening bakteri kandidat probiotik A.H. Condro Haditomo, S.Pi, M.Si. Penelitian ini dibiayai oleh Hibah Penelitian Fakultas Perikanan dan Ilmu Kelautan dengan sumber dana APBN DPA SUKPA.

\section{DAFTAR PUSTAKA}

Abumourad, I.M.K., Kenwy, A.M., Ibrahim, T.B., Hanna, M.I., \& Soliman, W.S. (2014). Enterococcus Faecium Probiotic As A Growth Promoter And Its Impact On The Expression Of The Host Innate Immune In Cultured Oreochromis Niloticus. Reseach Journal Of Pharmaceutical, Biological, And Chemical Sciences, 5(2), 17471761.

Agustin, R. A D. Sasanti , Yulisman. 2014. Konversi Pakan, Laju Pertumbuhan, Kelangsungan Hidup dan Populasi Bakteri Benih Ikan Gabus (Channa Striata) yang Diberi Pakan dengan Penambahan Probiotik. Jurnal Akuakultur Rawa Indonesia, 2(1) :55- 66.

Agusina, Putri. 2017. Kajian Bacillus methylothropicus Sebagai Bakteri Kandidat Probiotik dengan Konsentrasi Berbeda pada Media Budidaya Ikan Nila (Oreochromis niloticus) yang diberi Aeromonas Hydrophila SKRIPSI. Fakultas Perikanan dan Ilmu Kelautan. Undip: Semarang.

Aji, A.P, A.T.N. Charisma, A. Adianto, K. Umam, L. Manik, M.I. Husein, Rinda U. Likandi, Salsabila, dan S. Rosyanah. Seleksi Bakteri Probiotik Untuk Nutrisi. 2014. Laporan Praktikum Bioteknologi Akuakultur Laboratorium Reproduksi dan Genetika Ikan Departemen Budidaya Perairan. FPIK. Institut Pertanian Bogor.

Ardita, N. A. Budiharjo., dan S.L. Arumsari. 2015. Pertumbuhan dan Rasio Konversi Pakan Ikan Nila (Oreochromis niloticus) dengan Penambahan Probiotik. Jurnal Bioteknologi. 12(1): 16-21.

Bangsa, P. C. Sugito. Zuhrawati.. R. Daud. N. Asmilia., dan Azhar. 2015. Pengaruh Peningkatan Suhu Terhadap Jumlah Eritrosit Ikan Nila (Oreochromis niloticus).Jurnal Medika Veterinaria. 9(1).

Blaxhall, P. C and K. W. Daisley 1973. Routine Haematological Method for Use with Fish Blood. J. Fish Biol., 5: 577-581.

Fadri, S. Z A. Muchlisin, S.Sugito. 2016. Pertumbuhan, Kelangsungan Hidup Dan Daya Cerna Pakan Ikan Nila (Oreochromis Niloticus) Yang Mengandung Tepung Daun Jaloh (Salix Tetrasperma Roxb) Dengan Penambahan Probiotik Em-4. Jurnal Ilmiah Mahasiswa Kelautan Dan Perikanan Unsyiah 1(2) : 210-221. 
Fauziah, P. N. Nurhajati, J.,\& Charysanti. 2013. Daya Anti Bakteri Filtrat Asam Laktat Dan Bakteriosin Laktobacillus Bulgaricus Dalam Soygurt Terhadap Pertumbuhan Klebsiella Pneumonia. Bionatura Jurnal Ilmu-Ilmu Hayati Dan Fisik. Vol. 15, No. 2. 132-138.

Haditomo, A.H.C. A.M, Lusiastuti., dan Widanarni. 2016. Studi Bacillus Firmus Sebagai Kandidat Probiotik dalam Menghadapi Aeromonas Hydrophila Pada Media Budidaya. Jurnal Saintek Perikanan 2(11): 111-114.

Haditomo, A.H.C. Sarjito, Desrina dan S. Budi Prayitno. 2017. Screening Of Isolated Potential Probiotic From MudAquaculture In Central Java Indonesia With Molecular Based. Handbook Of The 10 Symposium On Diseases In Asian Aquaculture (Daal0).

Haetami,K. Abun., dan Y. Mulyani. 2008. Studi Pembuatan Probiotik Bas (Bacillus Licheniformis, Aspergillus Niger, Dan Sacharomices Cereviseae) Sebagai Feed Suplement Serta Implikasinya Terhadap Pertumbuhan Ikan Nila Merah. Laporan Penelitian.

Hanief, M.A.R. Subandiyono, dan Pinandoyo. 2014. Pengaruh Frekuensi Pemberian Pakan Terhadap Pertumbuhan Dan Kelulushidupan Benih Tawes (Puntius Javanicus). Journal Of Aquaculture Management And Technology. 3(4):67-74

Hardi, E. H. Sukenda, E. Harris, dan A.M. Lusiastuti. 2011. Karakteristik dan atogenitas Streptococcus Agalactiae Tipe $\beta$-hemolotik dan Non-Hemolitik pada Ikan Nila. Jurnal Veteriner. Vol 12. No 2: 152-164.

Hong H. A, Duc L. H, Cutting S. M. 2005. The use of bacterial spore formers as probiotics. Microbiology Reviews. 29:813-835.

Ihsanudin, I., S. Rejeki., dan T. Yuniarti. 2014. Pengaruh Pemberian Rekombinan Hormon Pertumbuhan (rGH) melalui Metode Oral dengan Interval Waktu yang Berbeda terhadap Pertumbuhan dan Kelulushidupan Benih Ikan Nila Larasati (Oreochromis niloticus). J. of Aqua. Manag. and Tech., 3(2): 94-102.

Indriani, A.D. S.B. Prayitno .,dan Sarjito. 2014. Penggunaan Ekstrak Jahe Merah (Zingiber Officinale Var. Rubrum) Sebagai Alternatif Pengobatan Ikan Nila (Oreochromis Niloticus) Yang Diinfeksi Bakteri Aeromonas Hydrophila Journal Of Aquaculture Management And Technology. 3(3): 58-65.

Lagler K.F, Bardach J.E, R.R Miller, Passino D.R.M. 1977. Ichthyology. John Willey and Sons. Inc. new YorkLondon. Hlm 506.

Lusiastuti, A.M. M.F. Ulkhaq. Widanarni., T.H. Prihadi. 2016. Evaluasi Pemberian Probiotik Bacillus Pada Media Pemeliharaan Terhadap Laju Pertumbuhan Dan Perubahan Histopatologi Ikan Lele Dumbo (Clarias Gariepinus) Yang Diinfeksi Aeromonas Hydrophila. Jurnal Riset Akuakultur, 11 (2):171-179.

Matofani, A.S. S.Hastuti., F. Basuki. 2013. Profil Darah Ikan Nila Kunti (Oreochromis Niloticus) Yang Diinjeksi Streptococcus Agalactiae dengan Kepadatan Berbeda. Journal Of Aquaculture Management And Technology. 2(2) : 64-72.

Mulyadi, A.E. 2011. Pengaruh Pemberian Probiotik pada Pakan Komersil Terhadap Laju Pertumbuhan Benih Ikan Patin Siam (Pangasius hypophthalamus). SKRIPSI. Fakultas Perikanan dan Ilmu Kelautan. Unpad: Jatinangor.

Nastiti, Nindiya. 2017. Pengaruh Penambahan Serbuk Kulit Kayu Manis (Cinnamomum burmannii) dalam Pakan untuk Pengobatan Ikan Nila (Oreochromis niloticus) yang Diinfeksi Aeromonas hydrophila. SKRIPSI. Fakultas Perikanan dan Ilmu Kelautan. Undip: Semarang.

Nasution, A. S. I., F. Basuki,. S. Hastuti. 2014. Analisis Kelulushidupan dan Pertumbuhan Benih Ikan Nila Saline Strain Pandu (Oreochromis niloticus) yang Dipelihara di Tambak Tugu, Semarang dengan Kepadatan Berbeda. J. Of Aqua. Manag. and Tech., 3 (2) : 25-32.

Putra, A. N. 2010. Kajian Probiotik, Prebiotik dan Sinbiotik Untuk Meningkatkan Kinerja Pertumbuhan Ikan Nila (Oreochromis niloticus). Tesis. Program Pasca Sarjana. Institut Pertanian Bogor. Bogor. 91 hlm (tidak diterbitkan).

Royan, F. S. Rejeki., dan A. H. C. Haditomo. 2014. Pengaruh Salinitas Yang Berbeda Terhadap Profil Darah Ikan Nila (Oreochromis niloticus). Journal Of Aquaculture Management And Technology 3(2) : 109-117.

Sainah, Adelina., dan B.Heltonika. 2016. Penambahan Bakteri Probiotik (Bacillus Sp) Isolasi Dari Giant River Frawn (Macrobrachium rosenbergii, De Man) Di Feed Buatan Untuk Meningkatkan Pertumbuhan Ikan Baung (Hemibagrus nemurus). Berkala Perikanan Terubuk. 44(2) : 36-50.

Septiana M. A, M.Agus., H. Pranggono. 2017. Pengaruh Pemberian Probiotik Dengan Dosis Yang Berbeda Terhadap Pertumbuhan Benih Ikan Bandeng (Chanos chanos Forksal). PENA Akuatika 15(1).

Setyanto. A. E. 2005. Memperkenalkan Kembali Metode Eksperimen dalam Kajian Komunikasi. Jurnal Ilmu Komunikasi. 1(3): $37-48$.

Sukenda, M. M. Rafsyanzani, Rahman, D. Hidayatullah. 2016. Kinerja probiotik Bacillus sp. pada pendederan benih ikan lele Clarias sp. yang diinfeksi Aeromonas hydrophila. Jurnal Akuakultur Indonesia 15 (2):162-170.

Suminto dan D. Chilmawati. 2015. Pengaruh Probiotik Komersial pada Pakan Buatan Terhadap Pertumbuhan, Efisiensi Pemanfaatan Pakan, dan Kelulushidupan Benih Ikan Gurami (Osphronemus Gouramy) D35-D75. Jurnal Saintek Perikanan. (11): 11-16. 
Tacon, A. E. J. 1987. The Nutrition and Feeding Formed Fish and Shrimp. a Training Manual Food and Agriculture of United Nation Brazilling , Brazil. 108 p.

Takeuchi, T. 1988. Laboratory Work Chemical Evaluation of Dietary Nutrient, p. 179 - 232. In: T. Watanabe (ed): Fish Nutrition and Mariculture. Kanagawa Fisheris Training Center, Japan Internasional Cooperation Agency, Tokyo.

Ulkhaq, M. F. Widanarni., A.M. Lusiastuti. 2014. Aplikasi Probiotik Bacillus Untuk Pencegahan Infeksi Aeromonas hydrophilla Pada Ikan Lele. Jurnal Akuakultur Indonesia 13 (2) : 105-114.

Wardika, A.S. Suminto., dan A. Sudaryono. 2014. Pengaruh Bakteri Probiotik Pada Pakan Dengan Dosis Berbeda Terhadap Efisiensi Pemanfaatan Pakan, Pertumbuhan Dan Kelulushidupan Lele Dumbo (Clarias Gariepinus). Journal Of Aquaculture Management And Technology. 3(4) : 9-17.

Widanarni, Elly, Soelityowati, D.T., \& Suwanto, A. 2008. Pemberian bakteri probiotik Vibrio SKT-b pada larva udang windu (Penaeus monodon) melalui pengkayaan Artemia. Jurnal Akuakultur Indonesia, (7): 129 -137.

Zuhrawati, N.A. 2014. Pengaruh Peningkatan Suhu Terhadap Kadar Hemoglobin Dan Nilai Hematokrit Ikan Nila (Oreocrhomis niloticus). Jurnal Medika Veterinaria. 8(1) 